\title{
NUTRITIONAL PROFILE AND BIOCHEMICAL ALTERATIONS IN NON- INSTITUTIONALIZED SENIOR CITIZENS WITH ALZHEIMER DISEASE: A CASE-CONTROL STUDY
}

\author{
PERFIL NUTRICIONAL E ALTERAÇÕES BIOQUIMICAS EM IDOSOS COM \\ DOENÇA DE ALZHEIMER NÃO INSTITUCIONALIZADOS: UM ESTUDO CASO- \\ CONTROLE
}

\author{
Bruno Bordin PELAZZA ${ }^{1 *}$; Patrícia Amâncio da ROSA²; \\ Loriane Francisca Tarnopolski BORGES ${ }^{3}$; Caroline PARIZOTTO $^{4}$; \\ Jéssica Duarte VERBANECK ${ }^{5}$; Dannyelle Cristina da SILVA ${ }^{6}$; \\ Guilherme Silva de MENDONÇA ${ }^{7}$; Weber Cláudio Francisco Nunes da SILVA ${ }^{8}$; \\ Juliana Sartori BONINI ${ }^{9}$
}

1*. Universidade Estadual do Centro-Oeste, Departamento de Enfermagem Guarapuava, Paraná, Brasil. brunobordin@unicentro.br; 2. Universidade Estadual do Centro Oeste, Mestranda do programa Ciências Farmacêuticas, Guarapuava, Paraná, Brasil;

3. Faculdade Guairacá, Guarapuava, Paraná, Brasil; 4. Universidade Estadual do Centro Oeste, Programa de Ciências Farmacêuticas Guarapuava, Paraná, Brasil; 5. Universidade Estadual do Centro Oeste, Programa Ciências Farmacêuticas; Guarapuava, Paraná, Brasil; 6. Universidade Estadual do Centro Oeste, Programa de Pós-Graduação stricto sensu em Ciências Farmacêuticas Departamento de Enfermagem, Guarapuava, Paraná, Brasil; 7. Universidade Federal de Uberlândia, Hospital de Clínicas de Uberlândia, Uberlândia, MG, Brasil; 8. Universidade Estadual do Centro-Oeste, Departamento de Farmácia, Guarapuava, Paraná, Brasil; 9. Universidade Estadual do Centro-Oeste, Departamento de Farmácia, Guarapuava, Paraná, Brasil.

ABSTRACT: Assess the nutritional and biochemical state of patients with Alzheimer Disease (AD) compared to a control group. This is an observational, case-control and descriptive type study, based on the recruiting of 22 elderly individuals with a clinical diagnosis of $\mathrm{AD}$ considered as the case group, and 22 other elderly individuals considered as the control group. Evaluations were made using the results from the following scales Mini Nutritional Assessment (MNA), Mini Mental State Examination (MMSE), anthropometric measurements for obtaining the body mass index (BMI) and biochemical analyses. The analyses were performed on the program SPSS version 20.0, using absolute and relative measures, $\mathrm{T}$ test for independent samples for measurement comparisons and the Spearman correlation test. In the cognitive evaluation MMSE, those participants with $\mathrm{AD}$ present higher risk of cognitive decline $(81.8 \%)$, greater risk of malnutrition according to MNA (45.5\%) and altered levels of leptin (90.9\%). Upon performing the comparison analysis between the group with $\mathrm{AD}$ and the control group, there existed noteworthy differences between the means for the variables MNA (4.40; BMI95\% 2.75 - 6.06), MMSE (10.54; BMI95\% 7.09 - 13.99) and doses of HDL (High Density Lipoproteins) (14.53; BMI95\% 6.18 - 22.88). As well as differences in the p-value $<0.09$ in the leptin doses (11.54; BMI95\% (-24.98 - 1.89) and transferrin dose (-72.31; BMI95\% -159.48 - 14.84). The Spearman correlation demonstrated that the cognitive decline in the group of senior citizens with AD was strongly associated with nutritional conditions MNA (R 0.484) and the leptin dose (R 0.590). Senior citizens with $\mathrm{AD}$ present worse nutritional conditions, cognitive decline and biochemical alterations when compared to senior citizens in the control group. As such, the study demonstrated the need for an integrated healthcare assistance concerning senior citizens with AD.

KEYWORDS: Biomarkers. Dementia. Leptin. Mental state assessment. Nutritional Assessment.

\section{INTRODUCTION}

Alzheimer's disease (AD) is a complex condition, classified as a chronic disease that leads to a progressive loss of cognitive, intellectual functions and abilities of memory, along with the alterations of physical functions and a decline in daily activities (LIANG et al., 2018). Pathological alterations of $\mathrm{AD}$ include the development of two distinct markers: the first, extracellular $\beta$-amyloid plaques $(\beta \mathrm{A})$ and the second, neurofibrillary tangles (NFTs) composed of hyperphosphorylated Tau proteins. These specific pathological findings accumulate in the cerebral and lead to cellular dysfunction and eventual neuronal loss, which externalize themselves as the clinical symptoms associated with AD (GRIZZANTI et al., 2016).

Among the numerous risk factors of the disease, age is considered the main one, as this is associated with the metabolic abnormalities related 
to the accumulation of fat, thus heavily contributing to an increase in oxidative stress (OS), inflammation, cognitive decline and the development of cognitive diseases (DAS et al., 2019; GRIZZANTI et al., 2016). Curiously, the higher adiposity in middle age seems to be associated with a higher risk of dementia, although some studies suggest that overweightness and obesity in advanced age can even be a protection against the risk of dementia (DAS et al., 2019; SALA FRIGERIO et al., 2019).

This paradox led researchers to search for and clarify the possible mechanisms through which corporal composition and neurological effects of various cell-signaling peptides, involved in the regulation of appetite and the ingestion of food nourishment, can influence the cerebral (GU et al., 2019). The fact is there still does not exist a full understanding into how these mechanisms combine to accelerate the development of AD (GRIZZANTI et al., 2016).

Among these adipokines, the signaling of leptin has gained considerable scientific attention as a potential therapy and biomarker for $\mathrm{AD}$ (ROMO; SCHOOLING, 2017). Leptin has demonstrated neurobiological effects that go beyond their role in body mass and systemic metabolism regulation, and as such act upon memory and plasticity (BONDA et al., 2014; HARVEY, 2015).

Is it possible, based on these scientific findings, to understand how nutritional, biochemical and metabolic disorders influence the development or progression of $\mathrm{AD}$ in elderly individuals?

Therefore, the objective of this study was to verify the nutritional profile and biochemical changes in senior citizens with non-institutionalized Alzheimer disease: a case-control study.

\section{MATERIALS AND METHODS}

\section{Design and location of study}

This is an observational and descriptive study of a case-control type, performed in the city of Guarapuava, Paraná, in the south of Brazil. Two groups of participants were included: the Alzheimer group, composed of senior citizens diagnosed with Alzheimer's disease and the control group, composed of senior citizens without dementia, matched by age and sex with the participants from the Alzheimer group.

The Association for Research Studies and the Alzheimer Support Group (AEPAPA) is characterized as a civil society that aims at providing assistance to this population and was thus created for this purpose. It is also responsible for providing home care for the elderly as a Public Service, according to law 2157/2013, specified in the Official Bulletin of the Municipality from 24 to 30 August 2013.

\section{Study population}

In the Alzheimer group, twenty-two senior citizens were included all diagnosed with $A D$, residents in the community and registered in the "Specialized Component of Pharmaceutical Assistance (SCPA), ordinance GM/MS no $1554 / 2013$ ", all of whom use the public health service network and receive specific medication for disease. The participants were identified through the Research Study Association and support group for Individuals with Alzheimer (AEPAPA). Excluded were participants who were not found at home after three contact visits at their residence for data collection purposes, those that did not complete the assessment and those that died during the period of the study.

In the control group, twenty-two senior citizens without dementia were included, residents in the community of the municipality, which met the matching variables adopted in the study: same age and sex as the participants in the Alzheimer group, but without the clinical diagnoses for AD. The participants from the control group were identified through the units for Strategic Family Health (SFH), and the Integrated Assistance Center (IAC) in the city of Guarapuava, from the registration for the Hyper-day Program (Hypertensive and Diabetic Program, Ordinance no. 2,583 on 10 October 2007) from the Ministry of Health. These three programs seek to promote life quality among the Brazilian population and to intervene quickly in factors that put health at risk. With comprehensive, equitable and continuous care, it contributes to strengthen the gateway to the Unified Health System (SUS), i.e., the public health system.

Participants who did not complete the assessment or died during the study period were excluded from the control group, and those who did not meet the corresponding parameters described in the inclusion criteria were also excluded. The minimental state examination (MMSE) was used as a screening tool to include participants in the control group, in which everyone should demonstrate a normal mental state. The criteria established for matching were the same age, same sex, besides smoking and/or diabetes mellitus and/or hypertension. 


\section{Data collection}

Data collection was performed by three trained researchers that used a protocol established by the study and always in the presence of the caregiver and / or family member. The interviewers were taught how to apply the questionnaire and given training for carrying out the anthropometric measurements, as well as how to manage the respective instruments/devices and scales used. The interviews occurred at the homes of the participants, between the months of March to December 2015.

\section{Cognitive Assessment}

To classify AD patients according to the stage of the disease, the Clinical Dementia Rating (CDR) scale was used, consisting in a questionnaire divided in categories (memory, orientation, judgment and problems solving, community relations, home and hobbies and personal cares) to evaluate patients according to an interview with the caregiver. Each category is classified based on the total scores corresponding to healthy (CDR 0), questionable (CDR 0.5), mild (CDR 1), moderate (CDR 2) or severe dementia (CDR 3) (MORRIS, 1993).

\section{Mental state evaluation}

The mental state of both groups was assessed by MMSE, a questionnaire which evaluates the cognitive function of elderlies by 30 questions evolving time and space orientation, attention and calculus, the evocation of memory and language (ALMEIDA, 1998; FOLSTEIN; FOLSTEIN; MCHUGH, 1975). In Brazil, cut-off points were adopted according to individuals education to indicate a healthy mental state, being 20 points to illiterates, 25, 26, 28 and 29 to individuals with 1-4, 5-8, 9-11 and more than 11 years of education, respectively (BRUCKI et al., 2003).

\section{Laboratory Exams}

The collecting of blood samples for performing the laboratory exams was performed at the very home of the patient, by trained researchers, according to the guidelines set by the Brazilian Society of Medical Laboratory Pathology for the collecting of venous blood (SBPC/ML, 2014). The determining of glucose concentrations was performed according to the guidelines of the kit used for measuring glucose through the enzymaticcolorimetric methodology, by Doorduijn method (DOORDUIJN et al., 2019), where the reference values were considered as normal for rates below $100 \mathrm{mg} / \mathrm{dL}$, for which kits supplied by Gold Analyzes Diagnostic (GAD) were used. In order to estimate triglycerides in serum the method used was enzymatic-colorimetric, using kits supplied by $G A D$, for triglycerides, those values considered normal were, while fasting less than $150 \mathrm{mg} / \mathrm{dL}$. In order to determine total cholesterol, values less than $200 \mathrm{mg} / \mathrm{dL}$ were considered adequate and for determining total cholesterol, the enzymaticcolorimetric kit for total cholesterol was used, provided by the company GAD. High-density lipoprotein (HDL) was obtained through precipitation methods for high-density lipoprotein and the levels of low-density lipoprotein (LDL) were obtained by applying the Friedewald formula (FRIEDEWALD; LEVY; FREDRICKSON, 1972). Normal values were considered as those higher than $40.0 \mathrm{mg} / \mathrm{dL}$ and less than $160 \mathrm{mg} / \mathrm{dL}$, respectively, which allowed for the obtainment of LDL values through the total cholesterol, triglycerides and HDL values (FRIEDEWALD; LEVY; FREDRICKSON, 1972). Albumin was measured through the colorimetric methodology Bromocresol Green using the Albumin assay kit (ALBUMIN PP) from $G A D$ and rates between 3.5-5.2 g/dL were considered normal. The assessing of aminotransferases, aspartate aminotransferase (AST) and alanine aminotransferase (ALT) was performed using the UV-kinetic method, the aminotransferases were considered altered when the values exceed $1.5 \mathrm{U} / \mathrm{L}$ the upper normality limit, for which a kit for quantitative determination of activity was used, both from the company $G A D$.

All the analyses described above were performed on biochemical semi-automated equipment CA 2006 manufactured by the SHEL B4B Group, at the laboratory of the Central West State University - UNICENTRO. However, the analysis for insulin was assessed by the chemiluminescent enzyme assay and the prealbumin and transferrin quantitative assessment were performed by nephelometry. The leptin dose was performed by the immunoradiometric assay (IRMA), while the folic acid and vitamin B12 assessments were performed using the automated Beckman Coulter $\AA$, with the chemiluminescent assay. Normal values for folic acid were considered as levels above $3.37 \mathrm{ng} / \mathrm{mL}$, and for vitamin B12, normal levels were those found between 300 to 900 pg/mL (FRIEDEWALD; LEVY; FREDRICKSON, 1972).

\section{Nutritional Assessment}

The body mass measurements were taken in accordance with the methods recommended by the Food and Nutrition Surveillance System (BRASIL, 2004). The body mass index (BMI) was calculated 
from the total body weight ratio in kilograms and height ${ }^{2}$ in meters, according to the recommendations by Lipschitz (1994). Senior citizens with a BMI below $17 \mathrm{Kg} / \mathrm{m}^{2}$ were classified as low weight, a BMI between 17 and $23 \mathrm{Kg} / \mathrm{m}^{2}$ were classified as eutrophic, while the results above $23 \mathrm{Kg} / \mathrm{m}^{2}$ were classified as overweight (BRASIL, 2004). The Mini Nutritional Assessment (MNA) was applied to evaluate the nutritional state of patients. This is an instrument composed of practical measures and questions that include anthropometric, global, dietetic (qualitative and quantitative) and a selfassessment of the patient. The score varies from 0 to 30 points, in which above 24 points indicates adequate nutritional state; a score between 23.5 and 17.5 points indicates a high risk of malnutrition and below 17 points, malnutrition (VELLAS et al., 2006)

\section{Ethical aspects}

The ethical precepts of resolution $466 / 12$ were respected; all participants that accepted their introduction into the study signed the Term of Free and Informed Consent - TCLE. The project was approved by the Ethics Committee for Research on Human Beings at the Central West State University of Paraná, according to opinion 968.931.

\section{Statistical analysis}

The data were analyzed using the Statistical Package for the Social Sciences (SPSS) version 20.0. Initially, the data were mapped to detect outliers. To describe the general characteristics of the population, absolute and relative frequencies were processed. The Shapiro-Wilk was applied in order to investigate conformity with the assumption of normality. The independent $t$ test was applied to unpaired samples between the groups Alzheimer and control.

The Spearman correlation test was used to analyze the relationships between the variables. All the analyses obey the significance criteria when $p$ $<0.05$ and the confidence interval is $95 \%$.

\section{RESULTS}

The clinical characteristics of the MMSE scale and biochemical factors of the case patients (with $\mathrm{AD}$ ) and control (without $\mathrm{AD}$ ) are demonstrated on Table 1. Highlighted from the Alzheimer's group is the higher prevalence of cognitive decline (81.8\%), higher nutritional risk $(45.5 \%)$, altered levels of transferrin (63.6\%), leptin (90.9\%) and HDL-C (72.7\%).

Table 1. Clinical characteristics for the MMSE and biochemical assessment of the patients from the case and control group, Guarapuava - PR, 2015.

\begin{tabular}{|c|c|c|c|c|}
\hline \multirow{2}{*}{ Parameter } & \multicolumn{2}{|c|}{ Alzheimer } & \multicolumn{2}{|c|}{ Control } \\
\hline & $\mathbf{N}$ & $\%$ & $\mathbf{n}$ & $\%$ \\
\hline \multicolumn{5}{|l|}{ Age Group } \\
\hline $60-69$ & 5 & 22.7 & 5 & 22.7 \\
\hline $70-79$ & 10 & 45.5 & 10 & 45.5 \\
\hline 80 or higher & 7 & 31.8 & 7 & 31.8 \\
\hline \multicolumn{5}{|l|}{ Education } \\
\hline 0 to 4 years & 20 & 90.9 & 17 & 77.3 \\
\hline 5 or more years & 2 & 9.1 & 5 & 22.7 \\
\hline \multicolumn{5}{|l|}{ Body Mass Index } \\
\hline Below weight & 8 & 36.4 & 8 & 36.4 \\
\hline Normal & 3 & 13.6 & 1 & 4.5 \\
\hline Overweight & 11 & 50.0 & 13 & 59.1 \\
\hline \multicolumn{5}{|c|}{ Nutritional Assessment } \\
\hline Adequate & 11 & 50.0 & 21 & 95.5 \\
\hline Nutritional risk & 10 & 45.5 & 1 & 4.5 \\
\hline Malnutrition & 1 & 4.5 & - & - \\
\hline \multicolumn{5}{|c|}{ Cognitive Assessment } \\
\hline No decline & 4 & 18.2 & 20 & 90.9 \\
\hline With decline & 18 & 81.8 & 2 & 9.1 \\
\hline \multicolumn{5}{|l|}{ Folic acid } \\
\hline Normal & 22 & 100.0 & 22 & 100.0 \\
\hline Altered & - & - & - & - \\
\hline \multicolumn{5}{|l|}{ Vitamin B12 } \\
\hline Normal & 18 & 81.8 & 19 & 86.4 \\
\hline Undetermined & 1 & 4.5 & 3 & 13.6 \\
\hline
\end{tabular}


Nutritional profile...

PELAZZA, B. B. et al.

Altered/deficient
Transferrin

Normal

Altered

Prealbumin

Normal

Altered

Leptin

Normal

Altered

Insulin

Normal

Altered

Total cholesterol

Normal

Altered

HDL-C $* * * * *$

Normal

Altered

Triglycerides

Normal

Altered

VLDL***

Normal

Altered

LDL $^{* * * * *}$

Normal

Altered

Albumin

Normal

Altered

AST*

Normal

Altered

ALT**

Normal

Altered
13.6

36.4

63.6

14

22

.

2

20

22

$-$

19

3

6

16

11

11

14

8

19

3

12

10

22

22

9.1

90.9

100.0

-

86.4

13.6

27.3

72.7

50.0

50.0

63.6

36.4

86.4

13.6

54.5

45.5

100.0

18

81.8

18.2

4

22

100.0

8

14

36.4

63.6

95.5

4.5

59.1

40.9

9

63.6

36.4

59.1

40.9

77.3

22.7

5

59.1

13

40.9

40.9

59.1

13

100.0

22

-

100.0

$\mathrm{n}=$ number; $\%=$ percentage. $*$ Aspartate Transaminase. ${ }^{* *}$ Aspartate aminotransferase. $* * *$ Lipoprotein of very low density. ${ }^{* * * *}$ Lipoprotein of low density. $* * * * *$ Lipoprotein of high density.

Figure 1 demonstrates the size of the effect (Hedges), as such one notes greater cognitive decline in MMSE with $1.85 \mathrm{~g}$ and risk of malnutrition assessed by MNA with $1.60 \mathrm{~g}$ in Alzheimer's patients when compared to the control group. 


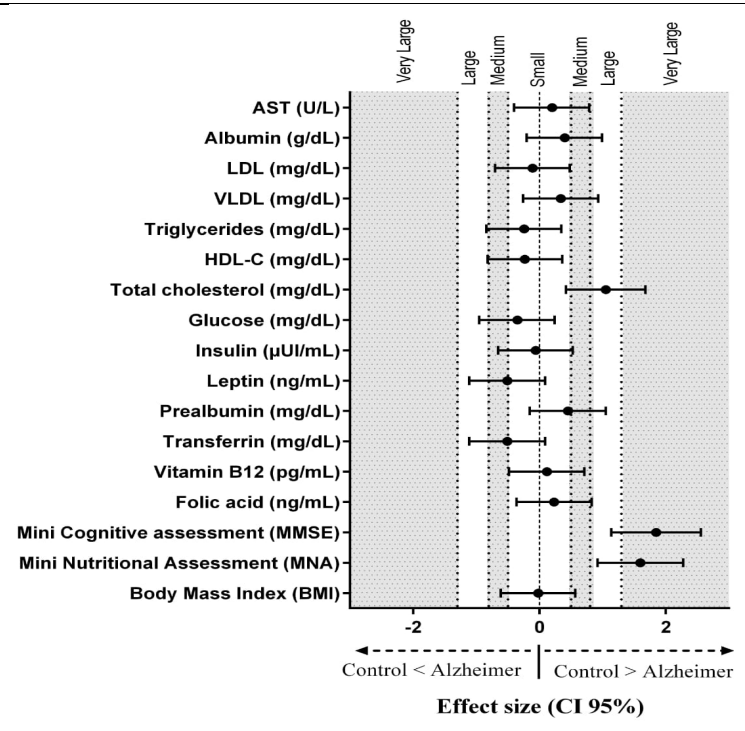

Figure 1. Effect size (Hedges) with 95\% confidence interval (CI) for the different means of serum dosages, MMSE, MNA and BMI, Guarapuava - PR, 2015.

Table 2 presents the mean for comparisons between the Alzheimer and control groups. Significant differences were noted in the MNA, MMSE and HDL variables and between the variables of cholesterol, leptin and transferrin, presented levels close to the significant. Upon comparing the means, there appear some noteworthy differences, senior citizens in the control group present $4.40(\mathrm{CI} 95 \% 2.75-6.06),\left[t_{(-5,40)}=\right.$ 37,01] points more than the Alzheimer group in relation to nutritional assessment. Noteworthy in the control group was that it obtained on mean 10.54 (CI 95\% $7.09-13.99),\left[t_{(-6,24)}=29,52\right]$ points more in the cognitive evaluation with the senior citizens presenting $\mathrm{AD}$. When analyzing the doses of cholesterol HDL the control group obtained 14.53 (CI 95\% $6.18-22.88),\left[t_{(-3,54)}=31,58\right]$ points more when compared to the Alzheimer group. Noted also was that the control group obtained on mean of $10.54($ CI $95 \% 7.09-13.99)\left[t_{(-6,24)}=29,52\right]$ points more in the cognitive assessment when compared to senior citizens presenting AD. The analysis of the cholesterol HDL doses showed that the control group obtained 14.53 (CI95\% $6.18-22.88$ ) points more in comparison to the Alzheimer group. Highlighted here is those variables that obtained values close to the significance level in relation to the serum leptin dosage, the senior citizens presenting AD obtained on mean -11.54 (CI 95\% ($24.98-1.89),\left[t_{(1,73)}=41,99\right]$ points more in comparison to the control group. The selfsame phenomenon was noted in relation to the levels of transferrin, where the senior citizen from the Alzheimer group obtained -72.31 (CI 95\% (-159.48 $-14.84),\left[t_{(1,71)}=22,46\right]$ points more in relation to the control group. Regarding cholesterol, the control group 25.07 (CI 95\% (-3.56 - 53.70), $\left[t_{(1,76)}=\right.$ $35,29]$ points more when compared to the senior citizens presenting $\mathrm{AD}$.

Table 2. Clinical comparison of the MNA, MMSE and biochemical between the patients from the case and control group, Guarapuava - PR, 2015.

\begin{tabular}{|c|c|c|c|c|c|c|}
\hline \multirow[b]{2}{*}{ Parameter } & \multicolumn{2}{|c|}{ Control $(n=22)$} & \multicolumn{2}{|c|}{ Alzheimer $(n=22)$} & \multirow{2}{*}{$\begin{array}{l}\text { Mean difference between } \\
\text { the groups } \\
(\mathrm{IC} 95 \%)\end{array}$} & \multirow[b]{2}{*}{$\begin{array}{c}p- \\
\text { value* }\end{array}$} \\
\hline & Mean & $\begin{array}{l}\text { Standard } \\
\text { deviation }\end{array}$ & Mean & $\begin{array}{l}\text { Standard } \\
\text { deviation }\end{array}$ & & \\
\hline Body Mass Index (BMI) & 27.41 & 3.67 & 27.49 & 5.16 & $\begin{array}{c}0.07 \\
(-2.64-2.80)\end{array}$ & 0.95 \\
\hline $\begin{array}{l}\text { Mini Nutritional Assessment } \\
\text { (MNA) }\end{array}$ & 26.52 & 2.15 & 22.11 & 3.16 & $\begin{array}{c}4.40 \\
(2.75-6.06)\end{array}$ & 0.00 \\
\hline $\begin{array}{l}\text { Mini Cognitive assessment } \\
\text { (MMSE) }\end{array}$ & 25.27 & 3.31 & 14.72 & 7.19 & $\begin{array}{c}10.54 \\
(7.09-13.99)\end{array}$ & 0.00 \\
\hline $\begin{array}{l}\text { Folic acid } \\
(\mathrm{ng} / \mathrm{mL})\end{array}$ & 13.02 & 6.46 & 11.49 & 6.42 & $\begin{array}{c}1.52 \\
(-2.39-5.44)\end{array}$ & 0.43 \\
\hline
\end{tabular}


PELAZZA, B. B. et al.

\begin{tabular}{|c|c|c|c|c|}
\hline $\begin{array}{l}\text { Vitamin B12 } \\
(\mathrm{pg} / \mathrm{mL})\end{array}$ & 320.36 & 151.48 & 300.50 & 183.86 \\
\hline $\begin{array}{l}\text { Transferrin } \\
(\mathrm{mg} / \mathrm{dL})\end{array}$ & 238.18 & 36.23 & 310.50 & 194.02 \\
\hline $\begin{array}{l}\text { Prealbumin } \\
\text { (mg/dL) }\end{array}$ & 27.69 & 8.45 & 24.46 & 5.33 \\
\hline $\begin{array}{l}\text { Leptin } \\
(\mathrm{ng} / \mathrm{mL})\end{array}$ & 16.24 & 22.02 & 27.78 & 22.14 \\
\hline $\begin{array}{l}\text { Insulin } \\
(\mu \mathrm{UI} / \mathrm{mL})\end{array}$ & 8.14 & 5.47 & 8.49 & 5.51 \\
\hline $\begin{array}{l}\text { Glucose } \\
(\mathrm{mg} / \mathrm{dL})\end{array}$ & 125.30 & 50.08 & 140.81 & 74.31 \\
\hline $\begin{array}{l}\text { Total cholesterol } \\
\qquad(\mathrm{mg} / \mathrm{dL})\end{array}$ & 186.69 & 56.39 & 161.62 & 35.35 \\
\hline $\begin{array}{l}\text { HDL-C***** } \\
\qquad(\mathrm{mg} / \mathrm{dL})\end{array}$ & 50.57 & 17.04 & 36.03 & 8.86 \\
\hline $\begin{array}{l}\text { Triglycerides } \\
(\mathrm{mg} / \mathrm{dL})\end{array}$ & 151.71 & 100.65 & 175.10 & 98.15 \\
\hline $\begin{array}{l}\text { VLDL*** } \\
(\mathrm{mg} / \mathrm{dL})\end{array}$ & 30.35 & 20.12 & 35.28 & 19.49 \\
\hline $\begin{array}{l}\mathrm{LDL} * * * * \\
(\mathrm{mg} / \mathrm{dL})\end{array}$ & 105.76 & 56.38 & 89.79 & 34.21 \\
\hline $\begin{array}{l}\text { Albumin } \\
(\mathrm{g} / \mathrm{dL})\end{array}$ & 3.66 & 0.61 & 3.74 & 0.80 \\
\hline $\begin{array}{l}\mathrm{AST}^{*} \\
(\mathrm{U} / \mathrm{L})\end{array}$ & 23.80 & 4.66 & 21.63 & 6.04 \\
\hline $\begin{array}{c}\mathrm{ALT}^{* *} \\
(\mathrm{U} / \mathrm{L})\end{array}$ & 16.30 & 12.34 & 14.38 & 5.80 \\
\hline
\end{tabular}

$*=$ Test $\mathrm{t}$ for independent samples. ${ }^{*}$ Aspartate Transaminase. ${ }^{* *}$ Aspartate aminotransferase. ${ }^{* * *}$ Very low-density lipoprotein. ${ }^{* * * *}$ Low density lipoprotein. ${ }^{* * * * *}$ High density lipoprotein.

From Table 3, one concludes that in the Alzheimer group there exists a positive correlation between the levels of cognitive decline (MMSE) with the nutritional assessment (MNA) and the leptin doses, that is, the higher the levels of decline worse will be nutritional conditions and higher the leptin levels. However, the nutritional evaluation was positively related to cognitive decline and the levels of leptin, and negatively to the levels of cholesterol, that is, the higher the level on the nutrition assessment scale, lower will be the cholesterol levels.
In the control group, one can conclude that there exists a positive relationship between the levels of cognitive decline (MMSE) with the nutritional assessment (MNA), levels of cholesterol HDL and leptin doses, showing in the same way the relationship of the cognitive state to these variables. Higher levels in nutritional assessment were reported positively with the levels of cholesterol. The leptin doses were positively correlated with the levels of cholesterol and transferrin, as demonstrated on Table 4. 
Table 3. Spearman correlation matrix rho for the variables of cognitive decline, nutritional assessment and serum doses in the Alzheimer's group, Guarapuava - PR, 2015.

** The correlation is significant at level $\leq 0.01 ;{ }^{*}$ the correlation is significant at level $\leq 0.05 .{ }^{1}$ Mini Mental State Exam. ${ }^{2}$ Mini Nutritional Assessment. ${ }^{3}$ High Density Lipoprotein

\begin{tabular}{|c|c|c|c|c|c|c|c|c|c|c|c|c|}
\hline & \multicolumn{2}{|l|}{$\mathrm{MMSE}^{1}$} & \multicolumn{2}{|l|}{$\mathrm{MNA}^{2}$} & \multicolumn{2}{|c|}{ HDL-C $^{3}$} & \multicolumn{2}{|l|}{ LEPTIN } & \multicolumn{2}{|c|}{ CHOLESTEROL } & \multicolumn{2}{|c|}{ TRANSFERRIN } \\
\hline & Rho & p-value & Rho & p-value & Rho & p-value & Rho & p-value & Rho & p-value & Rho & p-value \\
\hline MMSE & 1.000 & - & $0.484 *$ & 0.011 & 0.036 & 0.437 & $0.590 * *$ & 0.002 & 0.202 & 0.184 & -0.334 & 0.64 \\
\hline MNA & $0.484 *$ & 0.011 & 1.000 & - & -0.067 & 0.389 & $0.675^{* *}$ & 0.000 & $-0.397 *$ & 0.034 & -0.214 & 0.169 \\
\hline HDL-C & 0.036 & 0.437 & 0.036 & 0.389 & 1.000 & - & -0.232 & 0.150 & -0.144 & 0.261 & 0.190 & 0.097 \\
\hline LEPTIN & $0.590 * *$ & 0.002 & $0.675 * *$ & 0.000 & -0.232 & 0.150 & 1.000 & - & 0.039 & 0.432 & -0.161 & 0.237 \\
\hline CHOLESTEROL & 0.202 & 0.184 & $-0.397^{*}$ & 0.034 & -0.144 & 0.261 & 0.039 & 0.432 & 1.000 & - & 0.197 & 0.190 \\
\hline TRANSFERRIN & -0.334 & 0.64 & -0.214 & 0.169 & 0.288 & 0.097 & -0.161 & 0.237 & 0.197 & 0.190 & 1.000 & - \\
\hline
\end{tabular}

Table 4. Spearman correlation matrix rho for the variables of cognitive decline, nutritional assessment and serum doses in the control group, Guarapuava - PR, 2015.

** The correlation is significant at level $\leq 0.01 ; *$ the correlation is significant at level $\leq 0.05$. *Mini Mental State Exam. ** Mini Nutritional Assessment. ***High Density Lipoprotein

\begin{tabular}{|c|c|c|c|c|c|c|c|c|c|c|c|c|}
\hline & \multicolumn{2}{|l|}{ MMSE } & \multicolumn{2}{|l|}{ MNA } & \multicolumn{2}{|l|}{ HDL-C } & \multicolumn{2}{|l|}{ LEPTIN } & \multicolumn{2}{|c|}{ CHOLESTEROL } & \multicolumn{2}{|c|}{ TRANSFERRIN } \\
\hline & Rho & p-value & Rho & p-value & Rho & p-value & Rho & p-value & Rho & p-value & Rho & p-value \\
\hline MMSE* & 1.000 & - & $0.604 * *$ & 0.001 & $0.389 *$ & 0.037 & $0.383^{*}$ & 0.039 & 0.333 & 0.065 & 0.138 & 0.270 \\
\hline $\mathrm{MNA}^{* *}$ & $0.604 * *$ & 0.001 & 1.000 & - & 0.290 & 0.096 & 0.292 & 0.093 & $0.493^{*}$ & 0.011 & 0.205 & 0.180 \\
\hline HDL-C*** & $0.389 *$ & 0.037 & 0.290 & 0.096 & 1.000 & - & 0.105 & 0.321 & 0.050 & 0.412 & 0.16 & 0.471 \\
\hline LEPTIN & $0.383^{*}$ & 0.039 & 0.292 & 0.093 & 0.105 & 0.321 & 1.000 & - & $0.504 * *$ & 0.008 & $0.473^{*}$ & 0.013 \\
\hline CHOLESTEROL & 0.333 & 0.065 & $0.493 *$ & 0.011 & 0.050 & 0.412 & $0.504 * *$ & 0.008 & 1.000 & - & 0.028 & 0.451 \\
\hline TRANSFERRIN & 0.138 & 0.270 & 0.205 & 0.180 & 0.16 & 0.471 & $0.473^{*}$ & 0.013 & 0.028 & 0.451 & 1.000 & - \\
\hline
\end{tabular}




\section{DISCUSSION}

The present study demonstrated a significant difference in the values for MNA and MMSE, which affirms that the increase in cognitive decline has a relationship with malnutrition and nutritional risk presented by patients that have $A D$ and corroborates that found in previous studies (DOORDUIJN et al., 2019). This suggests that assessing MNA in patients with $\mathrm{AD}$, these present higher risk of malnutrition when compared to the group without AD. Some epidemiological studies suggest that individuals that present dementia present also higher weight loss. As such, the relationship of malnourishment and the increase in the risk of mortality is significantly evident in patients with dementia (PESSOA, 2017).

There are some studies that have assessed the relationship between individual quality of life, including nutrition and diet with cognitive decline in senior citizens. This suggests an association between cognitive decline and nutritional deficiency in senior citizens that have dementia, reinforcing in this way the importance of nutritional intervention for improving cognitive functionality in individuals that still have not presented signs of dementia (PESSOA, 2017; FERNANDEZ-SANZ; RUIZCABARRE; GARCIA-ESCUDERO, 2019).

It is known that through the interaction between multiple nutrients, it is possible to prevent or delay cognitive decline. There are those studies that point out that a number of diets are associated with a lower risk of developing Alzheimer's disease. Specific nutrients, discussed below are related to processes in the development of Alzheimer's disease, such as the accumulation of $\beta$-amyloid protein, tau protein hyperphosphorylation, oxidative stress and increased inflammation (XEN et al., 2019; SOLFRIZZI et al., 2017; MORRIS, 2016; GOES et al., 2014; HARDMAN et al., 2016; SOLFRIZZI et al., 2011).

Evidence shows that the Mediterranean diet has demonstrated benefits regarding delays in cognitive decline of patients with Alzheimer's disease, through decreasing the inflammatory potential of the food consumed. This characteristic can be found in many vegetables and fruits, these are foods rich in antioxidant vitamins capable of decreasing oxidative stress. In addition to high ingestion of unsaturated fat, which contain polyphenols that aid in reducing $\beta$-amyloid plaques. The Mediterranean diet also contains low quantities of saturated fats and cholesterol, which could induce stiffness and loss of fluidity of neuronal membranes in large quantities. In this context, low levels of cholesterol cause a lower activation of $\beta$-secretase, thus preventing the deposition of $\beta$-amyloid plaques (FERNANDEZ-SANZ; RUIZ-CABARRE; GARCIA-ESCUDERO, 2019; MEDINA-REMON et al., 2017; ROMERO-PAREDES, 2016).

Among those nutrients that modulate $\mathrm{AD}$, emphasis is given to unsaturated fats, which are divided into two groups: Omega $3(\omega 3)$ and omega 6 ( $\omega 6)$, these are structures that contain more than one double bond between carbons in their chain. Both types of fatty acids compete for the same structures of the membrane cells. Therefore, higher quantities of $\omega 6$ acids hinder the conversion into eicosapentaenoic acid (EPA) and docosahexaenoic acid (DHA), thus increasing the synthesis of proinflammatory eicosanoids of $\omega 6$ acids, such as prostaglandins, thromboxanes and leukotrienes. Higher quantities of acid $\omega 6$ result in an increase in inflammatory and vasoconstricting functions. On the other hand, fatty acids $\omega 3$ are capable of reducing inflammation by competing with fatty acids $\omega 6$ and blocking the conversion of arachidonic acid and their pro-inflammatory factors, besides hindering the production of inflammatory mediators (MEDINA-REMON et al., 2017; PETERSSON; PHILIPPOU, 2016; ROMERO-PAREDES, 2016; BALWINDER et al., 2014).

The intake of foods that contain large amounts of vitamins, such as vitamin A, C, D and E, or complex $\mathrm{B}$ take on the preventative role in the development of $\mathrm{AD}$, due to antioxidant potential and a potent suppressor action to the inflammatory response. The composition of these foods presents still further nutritional benefits, such as flavonoids that, according to studies, possess a protector effect in neurodegenerative pathologies, in addition to the presence of acids that are capable of reducing hyperphosphorylation of tau protein, thus decreasing the activity of a kinase, known as CDK5 (FERNANDEZ-SANZ; RUIZ-CABARRE; GARCIA-ESCUDERO, 2019; PETERSSON; PHILIPPOU, 2016; BALWINDER et al., 2014; CAMPONOVA et al., 2017; ROOT et al., 2012; ESPOSITO, et al., 2004).

Our study presented reduced values for HDL and total cholesterol in the AD group when compared to the control group, which corroborated with other studies that found altered values for HDL and total cholesterol in patients with Alzheimer (MACEDO SAMPAIO, 2016; TYNKKYNEN et al., 2016; CAMPONOVA et al., 2017).

Through the knowledge that low concentrations of HDL is one of the factors that contribute to dyslipidemia, some studies indicate a possible association between deregulation of the 
lipid profile and Alzheimer disease. There are studies that state that high levels of HDL-C are associated with a lower risk of $\mathrm{AD}$, while the low levels of HDL-C are accompanied by hyperinsulinemia, which is a risk factor for the disease. In addition, cholesterol HDL is critical for the maturation of synapses, as well as maintaining synaptic plasticity, which influences $A \beta$ clearance and the formation of neurofibrillary tangles that are directly linked to the development and evolution of AD stages (BUTTON et al., 2019; GROSSI et al., 2018).

Taking into consideration the genetic base of $\mathrm{AD}$, dyslipidemias are factors that contribute to its development, due to the gene codifier of the apolipoprotein E (APOE) being considered the main transporter of cholesterol in the blood and the central nervous system (MACEDO SAMPAIO, 2016; TANG et al., 2019).

Total cholesterol is an important component of the cerebral that plays a fundamental role in neural function, and yet demonstrates that the cholesterol metabolism, specifically when it comes to its transportation, can be involved in the development of AD. In this way, the increase of total cholesterol can be a risk factor for developing Alzheimer (MACEDO SAMPAIO, 2016; CAMPONOVA et al., 2017; TANG et al., 2019). The study did not present significant results for cholesterol levels, which can be explained by the sample size, which is one of the limitations of the study. The authors in Button et al. (2019) demonstrated the link of low cholesterol levels to malnutrition.

In our study, the leptin serum levels present higher values in the AD group when related to the control group. It is known that leptin is a hormone produced mainly by adipose tissue, which acts upon the balance of energy and in the regulation of hunger, as well as playing a role in the regulation of synaptic memory and plasticity (HARVEY, 2015; BUTTON et al., 2019). In addition, leptin possesses a regulatory activity in tau hyperphosphorylation, the accumulation of this protein is the main factor for the formation of neurofibrillary tangles and as such, leptin levels are related to the development of AD (BONDA et al., 2014; HOLDEN et al., 2009). Our finding corroborates with that from Bonda et al. (2014), where in their case-control study increased levels of leptin were fund in the cerebrospinal fluid, hippocampus and in the blood, along with a decrease in leptin receptors in the cerebral of patients with $A D$, which suggests a deregulation in this signaling system.
Another important result from our study were increased values of transferrin in the Alzheimer group in relation to the control group. It is acknowledged that plasmatic proteins are responsible for providing indirect information concerning the visceral protein content of the individual and as such, serum albumin and transferrin are considered important nutritional markers. Metabolized mainly in hepatocytes, transferrin is responsible for the transporting of iron and its levels are affected by a series of diseases, among such one finds inflammation (PARK, MOON, 2014; JAHANSHAD; RAJAGOPALAN; THOMPSON, 2013). This serum increase of transferrin in patients with $\mathrm{AD}$ can be the result of the inflammatory process (CONTIN et al., 2015; PARK, MOON, 2014).

In this way, in inflammatory situations, the absorption of iron is reduced and Interleukin-1 stimulates the secretion of transferring (CONTIN et al., 2015; TRIPATHI et al., 2017).

In the Alzheimer group, the results demonstrated a significant association between MMSE, MNA, HDL and leptin values. The study by Tombini et al. (2016) established relationships between MNA and Alzheimer's as well as HDL levels, stating that patients with the most compromised nutritional status had higher cognitive decline and higher cholesterol levels. Leptin is a hormone produced by fat cells, previous studies have shown a strong association between MNA values and serum leptin levels in women. Previous results demonstrate the relationship of leptin with the development of Alzheimer's. However, further research is needed to clarify whether leptin is a modifier of Alzheimer's disease or a genetic target for it (ROMO; SCHOOLING, 2017; SANTOS et al., 2018).

Our study also showed associations between serum cholesterol levels and MNA values in the Alzheimer's group, corroborating previous results in which increased cholesterol levels relate to higher nutritional status of patients (FERNANDEZ-SANZ; RUIZ-CABARRE; GARCIA-ESCUDERO, 2019).

A limitation found in the present study was the small size of the sample group, which restricts the scope of findings. Studies with larger sample groups are necessary for estimating with greater precision the impact of the results reported herein.

\section{CONCLUSION}

The impairment of nutritional state, related to the increase in leptin levels and biochemical alterations, are some of the factors that contribute to 
neural deregulation and can in themselves be considered factors of risk toward the progression of neurodegenerative diseases.

Malnutrition, partial or total absence of some nutrients and biochemical changes occur predominantly in AD patients. Therefore, individuals with AD demonstrated higher levels of cognitive decline, worse nutritional status and higher levels of leptin. In addition, this study demonstrated a reduction in HDL in the AD group when compared to the control group, which is a risk factor for the development of the disease.

In this sense, the importance of more studies involving the senior citizen population becomes evident, mainly concerning those with $\mathrm{AD}$, in order that the relationship of nutritional intake to the development of the disease becomes clear. This in addition to the early diagnosis of biochemical alterations present in the patient with $\mathrm{AD}$, in order to bring to light the process of dementia and increase life quality.

\section{ACKNOWLEDGEMENTS}

The authors would like to extend their thanks to the Study Association Research and Assistance to Individuals with Alzheimer Disease (AEPAPA), to the Araucaria Foundation and to the Coordination of Improvement of Higher Level Personnel (CAPES). In addition, we would like to thank the National Council for Scientific and Technological Development (CNPQ).

RESUMO: Avaliar o estado nutricional e bioquímico de pacientes com Doença de Alzheimer (DA) comparando com um grupo controle. Materiais e métodos: trata-se de um tipo observacional, caso-controle e descritivo a partir do recrutamento de 22 idosos diagnosticados clinicamente com DA considerados grupo caso e outros 22 idosos considerados controle, foi utilizado a escala Mini Avaliação nutricional (MNA), Mini Exame do Estado Mental (MMSE), medidas antropométricas para obtenção do índice de massa corporal (IMC) e análises bioquímicas. As análises foram realizadas no programa SPSS versão 20.0, utilizou-se de medidas absolutas e relativas, teste $\mathrm{T}$ para amostras independentes para comparação de médias e o teste de correlação de Spearman. Na avaliação cognitiva MMSE os participantes com DA apresentaram maior prevalência de declínio cognitivo $(81,8 \%)$, maior prevalência de risco para desnutrição segundo MNA $(45,5 \%)$ e níveis alterados de leptina $(90,9 \%)$. Ao se realizar a análise de comparação o grupo com DA e o controle observou-se diferenças significativas entre as médias das variáveis MNA (4,40; IC95\% 2,75 - 6,06), MMSE (10,54; IC95\% 7,09 $13,99)$ e dosagens de HDL $(14,53$; IC95\% 6,18 - 22,88). E diferenças com o p-valor $<0,09$ nas dosagens de leptina $(11,54$; IC95\% $(-24,98$ - 1,89) e dosagem de transferrina $(-72,31$; IC95\% -159,48 - 14,84). A correlação de Spearman demonstrou que o declínio cognitivo no grupo de idosos com DA, esteve associado significativamente às condições nutricionais MNA $(\mathrm{R} 0,484)$ e dosagem de leptina $(\mathrm{R} 0,590)$. Idosos com DA apresentaram piores condições nutricionais, declínio cognitivo e alterações bioquímicas, ao compara-los com idosos controles. Desta forma, o estudo demonstra a necessidade de uma assistência integral a esses idosos. mental.

PALAVRAS-CHAVE: Avaliação Nutricional. Biomarcadores. Demência. Leptina. Teste de estado

\section{REFERENCES}

ALMEIDA, O. P. Mini Exame dos Estado Mental e o Diagnóstico de Demência no Brasil. Arquivos de Neuro-Psiquiatria, São Paulo, v. 56, n. 3B, 1998. https://doi.org/10.1590/s0004-282x1998000400014

BALWINDER, S.; PARSAIK, A. K.; MIELKE, M. M.; ERWIN, P. J.; KNOPMAN, D. S.; PETERSEN, R. C.; ROBERTS, R. O. Association of Mediterranean diet with Mild Cognitive Impairment and Alzheimer's disease: A Systematic Review and Meta-Analysis. Journal of Alzheimer's disease, Texas, v. 39, n. 2, p. 271-282, 2014. https://doi.org/10.3233/jad-130830

BONDA, D. J.; STONE, J. G.; TORRES, S. L.; SIEDLAK, S. L.; PERRY, G.; KRYSCIO, R., JICHA, G.; CASADESUS, G.; SMITH, M. A.; ZHU, X.; LEE, H. G. Dysregulation of leptin signaling in Alzheimer disease: Evidence for neuronal leptin resistance. Journal of Neurochemistry, Melbourne, v. 128, n. 1, p. 16272, 2014. https://doi.org/10.1111/jnc. 12380 
BRASIL. Sistema de Vigilância Alimentar e Nutricional (SISVAN). Protocolos do Sistema de Vigilância Alimentar e Nutricional - SISVAN na assistência à saúde. Brasília: Ministério da Saúde, 2004.

BRUCKI, S. M. D.; NITRINI, R.; CARAMELLI, P.; BERTOLUCCI, P. H. F.; OKAMOTO, I. H. Sugestões para o uso do mini exame do estado mental no Brasil. Arquivos de Neuropsiquiatria, São Paulo, v. 61, n. 3, p. 777-81, 2003.

BUTTON, E. B.; ROBERT, J.; CAFFREY, T. M.; FAN, J.; ZHAO, W.; WELLINGTON, C. L. HDL from an Alzheimer's disease perspective. Curr Opin Lipidol., Within, v. 30, n. 3, p. 224-234, 2019. https://doi.org/10.1097/mol.0000000000000604

CAMPONOVA, P.; LE PAGE, A.; BERROUGUI, H.; LAMOUREUX, J.; PAWELEC, G.; WITKOWSKI, M. J.; FULOP, T.; KHALIL, A. Alteration of High-Density Lipoproteins functionality in Alzheimer's disease patients. Can. J. Physiol. Pharmacol., Canadá, v. 314, p. 1-35, 2017.https://doi.org/10.1139/cjpp-2016-0710

CONTIN, C. M.; COELHO, S. B.; OLIVIO, M. B.; VIEIRA, M. R.; BAGLIOTTI, C. M. F.; CRIVELLENTI, L. Z.; BORIN-CRIVELLENTI, S., SANTANA, A. E. Proteínas de fase aguda: Revisão de literatura. Investig Med Veterinária, v. 14, n. 2, p. 73-6, 2015. http://dx.doi.org/10.26843/investigacao.v14i2.869

DAS, S.; SAIDO, T.; KARRAN, E.; HYMAN, B.; PERRY, V. H.; FIERS, M.; DE STROOPER, B. The major risk factors for Alzheimer's disease: Age, Sex and Genes, modulate the microglia response to A $\beta$ plaques. Cell Rep., Maryland Heights, v. 27, n. 4, p. 1293-1306, 2019. https://doi.org/10.1016/j.celrep.2019.03.099

DOORDUIJN, A. S.; VISSER, M.; VAN DE REST, O.; KESTER, M. I.; DE LEEUW, F. A.; BOESVELDT, S.; FIELDHOUSE, J. L. P.; VAN DEN HEUVEL, E. G. H. M.; TEUNISSEN, C. E.; SCHELTENS, P.; VAN DER FLIER, W. M.; DE VAN DER SCHUEREN, M. A. E. Associations of AD Biomarkers and Cognitive Performance with Nutritional Status: The NUDAD Project. Nutrients, v. 11, n. 5, p. 1161, 2019. https://doi.org/10.3390/nu11051161.

ESPOSITO, K.; MARFELlA, R.; CIOTOLA, M.; DI PALO, C.; GIUGLIANO, F.; GIUGLIANO, G.; D'ARMIENTO, M.; D'ANDREA, F.; GIUGLIANO D. Effect of a mediterranean-style diet on endothelial dysfunction and markers of vascular inflammation in the metabolic syndrome: a randomized trial. JAMA, Washington, v. 292, n. 12, p.1440-1446, 2004. https://doi.org/10.1001/jama.292.12.1440

FERNANDEZ-SANZ, P.; RUIZ-CABARRE, D.; GARCIA-ESCUDERO, V. Modulating Effect of Diet on Alzheimer's Disease. Disease, Basel, v. 7, n. 12, p. 01-32, 2019. https://doi.org/10.3390/diseases7010012

FOLSTEIN, M. F.; FOLSTEIN, S. E.; MCHUGH, P. R. "Mini-mental state" a practical method for grading the cognitive state of patients for the clinician. Journal of Psychiatric Research, Amsterdã, v. 12, p. 189-98, 1975. https://doi.org/10.1016/0022-3956(75)90026-6

FRIEDEWALD, W. T.; LEVY, R. I.; FREDRICKSON, D. S. Estimation of theconcentration oflow-density lipoprotein cholesterol in plasma, without use of the preparative ultracentrifuge. Clinical Chemistry, Washington, v. 18, n. 6, p.499-502, 1972. PMID: 4337382. https://doi.org/10.1093/clinchem/18.6.499

GOES, V. F.; MELLO-CARPES, P. B.; OLIVEIRA, L. O.; HACK, J.; MAGRO, M.; BONINI, J. S. Evaluation of dysphagia risk, nutritional status and caloric intake in elderly patients with Alzheimer's. Revista Latino Americana de Enfermagem, Ribeirão Preto, v. 22, n. 2, p. 317-24, 2014. https://doi.org/10.1590/01041169.3252 .2418

GRIZZANTI, J.; LEE, H. G.; CAMINS, A.; PALLAS, M.; CASADESUS, G. The therapeutic potential of metabolic hormones in the treatment of age-related cognitive decline and Alzheimer's disease. Nutr Res., v. 36, n. 12, p. 1305-15, 2016. https://doi.org/10.1016/j.nutres.2016.11.002 
GROSSI, M. F.; CARVALHO, M. D. G.; SILVEIRA, J. N.; GONÇALVES, G. S.; GOMES, K. B.; BICALHO, M. A.; SILVA, I. F. O. OxLDL plasma levels in patients with Alzheimer's disease. Arquivos de Neuropsiquiatria, São Paulo, v. 76, n. 4, p. 241-246, 2018. https://doi.org/10.1590/0004-282x20180012.

GU, A.; MALAHIAS, M. A.; STRIGELLI, V.; NOCON, A. A.; SCULCO, T. P.; SCULCO, P. K. Preoperative Malnutrition Negatively Correlates With Postoperative Wound Complications and Infection After Total Joint Arthroplasty: A Systematic Review and Meta-Analysis. Journal of Arthroplasty, Iowa, v. 34, n. 5, p. 10131024 2019; https://doi.org/10.1016/j.arth.2019.01.005

HARDMAN, R. J.; KENNEDY, G.; MACPHERSON, H.; SCHOLEY, A. B.; PIPINGAS, A. Adherence to a mediterranean-style diet and effects on cognition in adults: A qualitative evaluation and systematic review of longitudinal and prospective trials. Frontiers in Nutricion, Londres, v. 3, n. 22, 2016.

https://doi.org/10.3389/fnut.2016.00022

HARVEY, J. Chapter 41 - Leptin and Alzheimer's Disease. In: MARTIN, C.; PREEDY, V. (editors). Diet and Nutrition in Dementia and Cognitive Decline. Londres, 1. ed., p. 457-467, 2015.

https://doi.org/10.1016/b978-0-12-407824-6.00041-0

HOLDEN, K. F.; LINDQUIST, K.; TYLAVSKY, F. A.; ROSANO, C.; HARRIS, T. B.; YAFFE, K. Serum leptin level and cognition in the elderly: Findings from the Health ABC Study. Neurobiology of Aging., Amsterdã, v. 30, n. 9, p. 1483-9, 2009. https://doi.org/10.1016/j.neurobiolaging.2007.11.024

JAHANSHAD, N.; RAJAGOPALAN, P.; THOMPSON, P. M. Neuroimaging, nutrition, and iron-related genes. Cell Mol Life Sci., Berlim, v. 70, n. 23, p. 4449-61, 2013. https://doi.org/10.1007/s00018-013-1369-2

LIANG, J. H.; XU, Y.; LIN, L.; JIA, R. X.; ZHANG, H. B.; HANG, L. Comparison of multiple interventions for older adults with Alzheimer disease or mild cognitive impairment: A PRISMA-compliant network metaanalysis. Medicine, Within, v. 97, n. 20, p. e10744, 2018. https://doi.org/10.1097/md.0000000000010744

LIPSCHITZ, D. A. Screening for nutritional status in the elderly. Primary Care, Londres, v. 21, n. 1, p. 55-67, 1994. PMID: 8197257

MACEDO SAMPAIO, F. A dislipidemia como fator de risco para o desenvolvimento da doença de Alzheimer: uma Revisão Sistemática. TCC (Graduação -Medicina) -Universidade Federal da Bahia, Faculdade de Medicina da Bahia, Salvador, 2016. 34 f.: Il

MEDINA-REMON, A.; KIRWAN, R.; RAVENTUS, R. M. L.; ESTRUCH, R. Dietary patterns and the risk of obesity, type 2 diabetes mellitus, cardiovascular diseases, asthma, and neurodegenerative diseases. Critical

Reviews in Food Science and Nutrition, Londres, v. 58, n. 2, p. 262-296, 2017.

https://doi.org/10.1080/10408398.2016.1158690

MORRIS, J. C. The Clinical Dementia Rating (CDR): current version and scoring rules. Neurology, Minneapolis, v. 43, p. 2412-2414, 1993. https://doi.org/10.1212/WNL.43.11.2412-a

MORRIS, M. C. Nutrition and risk of dementia: overview and methodological issues. Ann. N.Y. Acad. Sci., New York, v. 1367, n. 1, p. 31-37, 2016. https://doi.org/10.1111/nyas.13047

PARK, R. J.; MOON, J. D. Low transferrin saturation is associated with impaired fasting glucose and insulin resistance in the South Korean adults: the 2010 Korean National Health and Nutrition Examination Survey.

Diabetic Medicine, Nova Jersey, v. 32, n. 5, p. 673-678, 2014. https://doi.org/10.1111/dme.12643

PESSOA, S. D. C. Intervenção Nutricional no Retardamento da Deterioração Cognitiva e Demência. Fac ciências da Nutr e Aliment Fac do Porto, Porto, 2017. 26 p. 
PETERSSON, S. D.; PHILIPPOU, E. Mediterranean Diet, Cognitive Function, and Dementia: A Systematic Review of the Evidence. Advances in nutrition, Oxford, v. 7, n. 5, p. 889-904, 2016.

https://doi.org/10.3945/an.116.012138

ROMERO-PAREDES, M. D. C.; REINOSO-BARBERO, L.; GONZÁLEZ-GÓMEZ, M. F.; BANDRÉSMOYA, F. Improving cardiovascular health in Spanish seafarers. Int Marit Health., v. 67, n. 1, p.3-8, 2016. https://doi.org/10.5603/imh.2016.0002

ROMO, M. L.; SCHOOLING, C. M. Examining the Causal Role of Leptin in Alzheimer Disease: A Mendelian Randomization Study. Neuroendocrinology, v. 105, n. 2, p. 182-8, 2017. https://doi.org/10.1159/000475713

ROOT, M. M.; MCGINN, M. C.; NIEMAN, D. C.; HENSON, D. A.; HEINZ, S. A.; SHANELY, R. A.; KNAB, A. M.; JIN, F. Combined fruit and vegetable intake is correlated with improved inflammatory and oxidant status from a cross-sectional study in a community setting. Nutrients, v. 4, n. 1, p. 29-41, 2012. https://doi.org/10.3390/nu4010029

SALA FRIGERIO, C.; WOLFS, L.; FATTORELLI, N.; THRUPP, N.; VOYTYUK, I.; SCHMIDT, I.; MANCUSO, R.; CHEN, W. T.; WOODBURY, M. E.; SRIVASTAVA, G.; MÖLLER, T.; HUDRY, E.; DAS, S.; SAIDO, T.; KARRAN, E.; HYMAN, B.; PERRY, V. H.; FIERS, M.; DE STROOPER, B. The major risk factors for Alzheimer's disease: Age, Sex and Genes, modulate the microglia response to A $\beta$ plaques. Cell Rep., Cambridge, v. 27, n. 4, p. 1293-1306, 2019. https://doi.org/10.1016/j.celrep.2019.03.099

SANTOS, T. B.N.; FONSECA, L. C.; TEDRUS, G. M. A.; BERNARDI, J. L. D. Alzheimer's disease: nutritional status and cognitive aspects associates with disease severity. Nutrition Hospitalaria, Madrid, v. 35 , n. 6, p. 1298-1304, 2018. https://doi.org/10.20960/nh.2067

SBPC/ML - Sociedade Brasileira de Patologia Clínica. Recomendações da Sociedade Brasileira de Patologia Clínica para Coleta de Sangue Venoso. 3 ed. Barueri, SP: Minha Editora, 2014.

SOLFRIZZI, V.; PANZA, F.; FRISARDI, V.; SERIPA, D.; LOGROSCINO, G.; IMBIMBO, B.P.; PILOTTO A. Diet and Alzheimer's disease risk factors or prevention: The current evidence. Expert Rev. Neurother, Londres, v.11, p. 677-708, 2011. https://doi.org/10.1586/ern.11.56

SOLFRIZZI, V.; CUSTODERO, C.; LOZUPONE, M.; IMBIMBO, B. P.; VALIANI, V.; AGOSTI, P.; SCHILARDI, A.; D'INTRONO, A.; LA MONTAGNA, M.; CALVANI, M.; GUERRA, V.; SARDONE, R.; ABBRESCIA, D. I.; BELLOMO, A.; GRECO, A.; DANIELE, A.; SERIPA, D.; LOGROSCINO, G.; SABBÁ, C.; PANZA, F. Relationships of Dietary Patterns, Foods, and Micro- and Macronutrients with Alzheimer's Disease and Late-Life Cognitive Disorders: A Systematic Review. Journal of Alzheimer's disease, Texas, v. 59, n. 3, p. 815-849, 2017. https://doi.org/10.3233/jad-170248

TANG, Y.; LI, Y-M.; ZHANG, M.; CHEN, Y-Q.; SUN, Q. ع3/4 genotype of the apolipoprotein E is associated with higher risk of Alzheimer's disease in patients with type 2 diabetes mellitus. Gene, Minnesota, v. 703, p. 65-70, 2019. https://doi.org/10.1016/j.gene.2019.03.024

TOMBINI, M.; SICARI, M.; PELLEGRINO, G.; URSINI, F.; INSARDÁ, P.; LAZZARO, V. Nutritional status of patients with alzheimer's disease and their caregivers. Journal of Alzheimers Disease, Texas, v.5, p.16191627, 2016. https://doi.org/10.3233/JAD-160261

TYNKKYNEN, J.; HERNESNIEMI, J. A.; LAATIKAINEN, T.; HAVULINNA, A. S.; SUNDVALL, J.; LEIVISKÄ, J.; SALO, P.; SALOMAA, V. Apolipoproteins and HDL cholesterol do not associate with the risk of future dementia and Alzheimer's disease: The National Finnish population study (FINRISK). AGE, Omaha, v. 38, n. 5-6, p. 465-73, 2016. https://doi.org/10.1007/s11357-016-9950-x 
TRIPATHI, A. K.; KARMAKAR, S.; ASTHANA, A.; ASHOK, A.; DESAI, V.; BAKSI, S.; SINGH, N. Transport of Non-Transferrin Bound Iron to the Brain: Implications for Alzheimer's Disease. Journal of Alzheimer's disease, Texas, v. 58, n. 4, p. 1109-1119, 2017. https://doi.org/10.3233/jad-170097

VELLAS, B.; VILLARS, H.; ABELLAN, G.; SOTO, M. E.; ROLLAND, Y.; GUIGOZ, Y.; MORLEY, J. E.; CHUMLEA, W.; SALVA, A.; RUBENSTEIN, L. Z.; GARRY, P. Overview of the MNA - Its history and challenges. J. Nutr. Health Aging, Paris, v. 10, n. 6, p. 456-463, 2006. PMID: 17183418

XEN, X.; MAGUIRE, B.; BRODATY, H.; O'LEARY, F. Dietary Patterns and Cognitive Health in Older Adults: A Systematic Review. Journal of Alzheimer's disease, Texas, v.67, p. 583-619, 2019.

https://doi.org/10.3233/jad-180468 